\title{
Elas são negras: trabalhadoras não escravizadas na cidade de Campinas (1876-1882) Taina Aparecida Silva Santos*
}

\begin{abstract}
Resumo
Ao longo da pesquisa, foi desenvolvido um levantamento das profissões e ocupações femininas em vigência na segunda metade do século XIX, na região do oeste paulista. O estudo foi realizado a partir do Registro de Matrícula de Enfermos do Hospital de Misericórdia da Santa Casa de Campinas. Foram analisados, aproximadamente, dois mil e trezentos registros de pessoas que deram entrada no hospital entre 1876 e 1882, enfocando os dados referentes à população de mulheres livres e libertas. Informações a partir das quais pude inferir aspectos da vida de mulheres negras não escravizadas presentes na localidade de Campinas. A listagem das informações e cruzamentos com outros dados contidos na fonte, possibilitou observar a configuração da distribuição dessas trabalhadoras no mercado de trabalho livre no período apontado. Esse esforço viabilizou a obtenção de um quadro da composição racial desse universo de trabalho, sob o qual pode-se perceber possíveis relações entre a distribuição de mulheres negras e brancas nas ocupações com os processos de racialização vigentes naquela sociedade e no momento em que a urbanização da região impactava a organização do trabalho urbano, o crescimento do setor de serviços e a expansão das políticas sanitaristas.
\end{abstract}

Palavras-chave: mulheres negras, trabalho livre, racialização

\section{Introdução}

O Brasil foi um dos locais em que mais foram emitidas alforrias onerosas durante o período escravista em todo o continente americano a ponto de, em $1872,15,2 \%$ da população brasileira ser composta por escravizados (as). A emancipação gradual da população negra ao longo do século XIX, além de pautar a reformulação das hierarquias sociais, impactou a distribuição de trabalhadores negros livres e libertos no mundo do trabalho. Movimento inflamado por tensões raciais que se manifestaram de diversas maneiras: desde a formulação e organização de leis para a regulação do trabalho e que visavam projetos de imigração branca em 1830 até a distribuição diferenciada e hierarquizada de cargos públicos baseada na cor da pele denunciada pelo primeiro jornal de imprensa negra. Um número considerável de historiadores e historiadoras tem desenvolvido estudos importantes e engajados em compreender os significados dessas tensões assim como dos sentidos da vida em liberdade para a população negra. Contudo, as investigações com foco nas experiências das mulheres negras livres e libertas ainda são tímidas tanto no campo da História Social do Trabalho como no da História das Mulheres.

\section{Resultados e Discussão}

A partir do estudo do Registro de Matrícula de Enfermos do Hospital de Misericórdia da Santa Casa, foi realizado um levantamento das profissões ocupadas por mulheres na localidade de Campinas e arredores com fim de observar as áreas de atuação do contingente feminino no trabalho urbano. Além disso, buscou-se obter mais informações sobre os processos de racialização naquele período, responsáveis por colocar a ideia de raça em ação estabelecendo distinções a partir das concepções raciais, por meio de exercícios políticos em contextos de profundas transformações. Além do levantamento das profissões exercidas por mulheres, a análise dos dados possibilitou comparações entre as ocupações desenvolvidas pelas populações brancas e negras. Foram compilados, aproximadamente, dois mil e trezentos dados do segundo livro de registro dos enfermos do hospital da
Santa Casa entre os anos de 1876 e 1892. As informações revelam padrões raciais na distribuição das mulheres pobres no mercado de trabalho urbano. Ao longo da pesquisa, também, foi feitos estudos bibliográficos sobre a história da cidade de Campinas, o conceito de racialização, as epistemologias feministas e leituras de obras sobre a história das mulheres, especial, das mulheres negras, durante o século XIX e XX.

\section{Conclusões}

Em um cenário de crescimento da região de Campinas, no qual é expressivo o número da população negra emancipada, as mulheres se destacam com representação expressiva no mercado de trabalho "livre". Entretanto, as mulheres negras estavam concentradas em profissões específicas e em que permanecem sendo a maioria até os tempos atuais. Os resultados dessa pesquisa apontam para a existência de um processo de racialização que, certamente, esteve relacionado às políticas de planejamento urbano marcadas pelo avanço do sanitarismo. A sociedade definida pelo escravismo e por complexas hierarquias raciais tornou a condição da população de mulheres negras livres e libertas precária, o que, certamente, contribuiu para a racialização da pobreza. Mesmo em condições adversas essas mulheres impactaram a economia da região, principalmente, na área de prestação de serviços.. Além disso, atormentaram 0 imaginário das elites que incomodavam-se com a presença desse contingente nos espaços públicos, principalmente, quando não correspondia aos anseios pré-estabelecidos pelos grupos dominantes.

Referências bibliográficas:

ALBUQUERQUE, W. O Jogo da dissimulação: abolição e cidadania negra no Brasil. São Paulo: Companhia das Letras, 2008.

CHALHOUB, Sidney. A força da escravidão: ilegalidade e costume no Brasil oitocentista. São Paulo: Companhia das Letras, 2012.

Cidade Febril: cortiços e epidemias na corte imperial. São Paulo: Companhia das Letras, 2017.

FARIAS, Sheila Siqueira de Castro. Sinhás Pretas, damas mercadoras: as pretas minas nas cidades do Rio de Janeiro e de São João Del Rei. Tese (Concurso para professora titular em História). Universidade Federal Fluminense, 2004. 